\title{
Intercropping in Okra for Sustainable Vegetable Production
}

\author{
P. Choudhuri ${ }^{{ }^{*}}$ and J. C. Jana ${ }^{2}$
}

${ }^{1}$ Dept. of Vegetable Crops, Faculty of Horticulture, BCKV, Mohanpur, Nadia, West Bengal (741 252), India

${ }^{2}$ Dept. of Vegetable and Spice Crops, Faculty of Horticulture, UBKV, Pundibari, Cooch Behar, West Bengal (736 165), India

\section{Article History}

Manuscript No. AR1398b

Received in $6^{\text {th }}$ July, 2015

Received in revised form $14^{\text {th }}$ May, 2016

Accepted in final form $20^{\text {th }}$ June, 2016

\section{Correspondence to}

*E-mail: partha2909@rediffmail.com

\section{Keywords}

Intercropping, okra, sustainable, quality parameters.

\begin{abstract}
A field experiment was conducted at the Instructional Farm of UBKV during rabi seasons of 2008 and 2009 to assess intercropping effect in okra with an objective to generate more income from the farm through increased cropping intensity and complete and economical use of natural resources by combining nine different treatment combinations of different intercrops like cowpea, amaranthus, radish and palak in 1:1 row ratio. The trial was laid out in randomized block design (RBD) with four replications. Experimental results indicated that sole cropping of okra recorded significantly maximum values for most of the vegetative parameters. Sole cropping of okra recorded maximum number of marketable fruits plot $^{-1}$ (1502.81), maximum fruit weight (17.11 g) and highest yield ha-1 (11.54 t). However, maximum okra equivalent yield ha-1 $(15.67 \mathrm{t})$ was observed in okra+cowpea intercropping system. Minimum value for the same $\left(9.02 \mathrm{t} \mathrm{ha}^{-1}\right)$ was recorded in okra+radish intercropping system. The study revealed that ascorbic acid content of the okra fruit was not significantly affected due to intercropping. Okra+cowpea intercropping system was found best user of biological resources as it recorded maximum values for LER (1.56), RCC (13.75) and lower values of aggressivity (-0.14) and competitive ratio (0.93). Economic analysis also showed that okra+cowpea intercropping system was most remunerative as it recorded highest net return and $\mathrm{B}: \mathrm{C}$ ratio ( $₹ 1,35,891.50$ and 2.61 , respectively). Based on the findings, growing of cowpea with okra may be adjudged as the best intercrop for sustainable vegetable production.
\end{abstract}

\section{Introduction}

India is the second largest producer of vegetable in the world after china. In 2012-13 India produced $162.90 \mathrm{mt}$ of vegetables from 9.40 mha area with a productivity of $17.30 \mathrm{tha}^{-1}$ in which West Bengal alone supplied $23.05 \mathrm{mt}$ which was nearly 20 percentage of the country's total vegetable production (NHB 2013-14). West Bengal is ideally suitable for cultivation of different vegetable crops. Among different vegetables grown, okra is a promising vegetable for the farmers of West Bengal. But the productivity of this crop is lower compared to national average. In India okra is popularly grown in mixtures with staple food crops such as yam, maize, cassava, cowpea and pepper or with various vegetable crops on small farm holdings (Odeleye et al., 2005). Among different plant production tools, intercropping of compatible crops can be of great value in achieving the improved productivity without requiring significant additional resources. The peasant farmers generally prefer the intercropping system because it produces higher total crop yield unit ${ }^{-1}$ area, provides insurance against total crop failure, and also reduces incidences of pests and diseases (Lyocks et al., 2013). The advantages of intercropping are risk minimization, effective use of available resources, efficient use of labour, increased crop productivity, erosion control and food security (Addo-quaye et al., 2011). Yield advantage occurs because growth resources such as light, water, and nutrients are more completely absorbed and converted to crop biomass by the intercrop over time and space as a result of differences in competitive ability for growth resources between the component crops, which exploit the variation of the mixed crops in characteristics such as rates of canopy development, final canopy size (width and height), photosynthetic adaptation of canopies to irradiance conditions, and rooting depth. Careful planning is required when selecting the component crops of a mixture, taking into account the environmental conditions of an area and the available crops or varieties. It was shown by many researchers that intercropping of different vegetable crops provided important advantages as well as higher profitability than vegetables grown as sole crops (Nursima, 2009). 
Moreover, because inorganic fertilizers have contributed to environmental damage such as nitrate pollution, legumes grown in intercropping are regarded as an alternative and sustainable way of introducing $\mathrm{N}$ into lower input agro ecosystems (Fustec et al., 2010). Keeping all these facts in mind, the present study has been undertaken to assess the influence of intercropping in okra for sustainable vegetable production.

\section{Materials and Methods}

The present experiment was carried out during rabi seasons of 2008 and 2009 at the instructional farm of Uttar Banga Krishi Viswavidyalaya, Pundibari, Cooch Behar,West Bengal. The climatic condition of characterized by high rainfall (250-300 $\mathrm{cm}$ annum $\left.{ }^{-1}\right)$, high relative humidity $(80-85 \%)$, moderate temperature $\left(25-30{ }^{\circ} \mathrm{C}\right)$ prolonged winter with high residual soil moisture. The treatments included $\mathrm{T}_{1}$ : Sole okra (control); $\mathrm{T}_{2}$ : Sole cowpea; $\mathrm{T}_{3}$ : Sole amaranthus $; \mathrm{T}_{4}$ : Sole radish; $\mathrm{T}_{5}$ : Sole palak; $\mathrm{T}_{6}$ : Okra+cowpea; $\mathrm{T}_{7}$ : Okra+amaranthus; $\mathrm{T}_{8}$ : Okra+radish; $\mathrm{T}_{9}$ : Okra+palak. The treatments were laid out in randomized block design with four replications. The variety used for okra was Arka Anamika. Recommended package of practices were followed for sole okra and sole intercrops. Seeds of intercrops were sown in between the rows of okra, spaced at $50 \times 50 \mathrm{~cm}^{2}$. In intercropping situations, all the intercrops received the package of practices as in case of the main crop, okra. Ascorbic acid content of fruit was determined by the procedure given by Ranganna, (1986) and was expressed in mg $100 \mathrm{~g}^{-1}$. The observations recorded from different treatments in the field for okra were subjected to statistical analysis by adopting the Randomized Block Design (RBD) method suggested by Panse and Sukhatme (2000).

\section{Results and Discussion}

\subsection{Growth parameters}

The pooled result, pertaining to growth characters, presented in Table 1, indicated that most of the growth attributes were significantly influenced due to intercropping. Sole cropping of okra recorded significantly maximum values for most of the growth characters like plant height $(98 \mathrm{~cm})$, leaf number (23.67) and root length $(10.65 \mathrm{~cm})$. On the other hand, okra+cowpea intercropping system also higher values for shoot weight (509.03 g), root weight $(23.70 \mathrm{~g})$, and root volume $(34.18 \mathrm{cc})$. Highest shoot to root ratio was recorded in okra+radish intercropping system (28.53). After sole cropping of okra, okra+cowpea system of intercropping has recorded higher values for most of the growth characters which might be due to better utilization of resources as there was lesser competition from the component crops for solar radiation, increasing plant height, leaf numbers, etc. compared to other intercropping treatments. This result is in conformity with the findings of (Sharma et al., 2009) in pearlmillet based intercropping system.

\subsection{Yield parameters}

Regarding yield parameters, maximum values for most of the characters were recorded in sole cropping of okra (Table 1 and 2). Similar observations were also recorded by Kandeyang (2004) in okra based intercropping system where yield of main crops were highest when they are grown alone compared to their intercropping. The plots where okra was grown alone recorded highest fruit weight (17.11 g), maximum number of marketable fruits plot $^{-1}(1502.81)$ and highest yield $\mathrm{ha}^{-1}(11.54 \mathrm{t}$ ). Maximum reduction in yield of intercrop over sole cropping was observed when radish was intercropped with okra (44.67\%). Among the intercropping treatments, okra+cowpea combination was found superior to other treatments of intercropping as it recorded higher values for yield parameters. However, maximum okra equivalent yield ha ${ }^{-1}$ was observed in okra + cowpea intercropping system (15.67 t). Similar type of observation was obtained by Singh (1993) where intercropping of okra with cowpea recorded maximum okra equivalent yield (24.98 $\left.\mathrm{t} \mathrm{ha}^{-1}\right)$ compared with $16.31 \mathrm{t} \mathrm{ha}^{-1}$ for pure okra. (Hadidi et al., 2011) also recorded highest yield of okra when it was intercropped with bean. Significantly higher yield was also obtained from okra (53\%) when grown with ground nut comparing to mono cropping (Nilanthi et al., 2015). In the present investigation, higher okra equivalent yield was recorded in okra+cowpea

Table 1: Effect of intercropping on growth and yield characters of okra (pooled data)

\begin{tabular}{lccccccccccc}
\hline Treatment & $\begin{array}{c}\text { Plant } \\
\text { height } \\
(\mathrm{cm})\end{array}$ & $\begin{array}{c}\text { No. of } \\
\text { leaves } \\
\text { plant }^{-1}\end{array}$ & $\begin{array}{c}\text { Shoot } \\
\text { weight } \\
(\mathrm{g})\end{array}$ & $\begin{array}{c}\text { Root } \\
\text { weight } \\
\text { plant }^{-1}(\mathrm{~g})\end{array}$ & $\begin{array}{c}\text { Shoot } \\
\text { to root } \\
\text { ratio }\end{array}$ & $\begin{array}{c}\text { Root } \\
\text { length } \\
(\mathrm{cm})\end{array}$ & $\begin{array}{c}\text { Root } \\
\text { volume } \\
\text { llant }^{-1}(\mathrm{cc})\end{array}$ & $\begin{array}{c}\text { Fruit } \\
\text { weight } \\
(\mathrm{g})\end{array}$ & $\begin{array}{c}\text { No. of } \\
\text { marketable } \\
\text { fruits plot }\end{array}$ & $\begin{array}{c}\text { Yield } \\
\left(\mathrm{t} \mathrm{ha}^{-1}\right)\end{array}$ & $\begin{array}{c}\text { Harvest } \\
\text { index } \\
(\%)\end{array}$ \\
\hline Sole okra & 98.00 & 23.67 & 499.70 & 20.39 & 24.57 & 10.65 & 31.40 & 17.11 & 1502.81 & 11.54 & 42.10 \\
Okra + cowpea & 87.33 & 20.80 & 509.03 & 23.70 & 21.54 & 9.49 & 34.18 & 13.46 & 1354.13 & 8.77 & 38.93 \\
Okra+amaranthus & 72.63 & 17.27 & 426.03 & 15.54 & 27.39 & 7.78 & 21.33 & 8.68 & 999.21 & 6.90 & 35.97 \\
Okra+ radish & 67.78 & 15.90 & 374.16 & 13.23 & 28.53 & 6.94 & 17.97 & 7.24 & 888.99 & 6.38 & 34.77 \\
Okra+palak & 77.41 & 18.01 & 449.03 & 17.37 & 26.01 & 8.54 & 25.16 & 11.09 & 1178.63 & 7.86 & 30.27 \\
SEm \pm & 2.87 & 1.29 & 23.27 & 0.79 & 5.78 & 0.61 & 1.64 & 0.51 & 79.47 & 0.51 & 0.89 \\
$\mathrm{CD}(p=0.05)$ & 8.31 & 3.75 & 67.42 & 2.32 & 1.98 & 1.77 & 4.75 & 1.50 & 230.21 & 1.47 & 2.57 \\
\hline
\end{tabular}


intercropping system than sole crop of okra which was due to increase in yield of okra through increase in number of fruits plant $^{-1}$, growth attributes and fruit weight as the main crop okra is slow growing, intercropping of fast growing legume like cowpea with higher market price is expected to give substantial yield advantage This result was further supported by the findings Hugar and Palled (2008) who observed that highest maize equivalent yield was obtained when maize was intercropped with French bean. Minimum value for the same was recorded in okra+radish intercropping system (9.02 $\mathrm{t}$ $\left.\mathrm{ha}^{-1}\right)$. After going through the Table 1, it was also observed that maximum value for harvest index $(42.10 \%)$ was found in sole okra plots which were significantly higher than all other system of intercropping with okra. Among the intercropping treatments, okra+cowpea system recorded maximum harvest index (38.93\%). (Matusso et al., 2014) also obtained highest harvest index $(37.30 \%)$ in maize+soybean intercropping system Significantly maximum production efficiency of the system (Table 2) was observed in okra+cowpea treatment $\left(195.88 \mathrm{~kg}^{-1} \mathrm{ha}^{-1} \mathrm{day}^{-1}\right)$. The study on quality parameters, presented in Table 2, revealed that ascorbic acid content of the okra fruit was not significantly affected due to intercropping. Maximum value of ascorbic acid content of okra fruit was observed in okra+cowpea intercropping system $(25.28 \mathrm{mg}$ $100 \mathrm{~g}^{-1}$ ) which was only statistically at par with that of sole okra (24.27 mg $\left.100 \mathrm{~g}^{-1}\right)$ but significantly superior to all other treatment combinations.

\subsection{Competitive functions}

Regarding competitive functions, presented in Table 2 okra + cowpea intercropping system was found best user of biological resources as it recorded maximum values for LER (1.56), RCC (13.75) and lower values of aggressivity (-0.14). Similar type of results were also obtained by Hugar and Palled (2008) in maize+French bean intercropping system, John and Mini (2005) in okra+cowpea intercropping system and Seran and Brintha (2009) in capsicum+vegetable cowpea intercropping model.

\subsection{Economics}

Economic analysis, presented in Table 2, showed that okra+cowpea intercropping system was most remunerative as it recorded highest net return and B:C ratio (₹ 1,35,891.50

\begin{tabular}{lcccccccc}
\hline Table 2: Effect of intercropping on yield, quality, competitive functions and economics of okra (pooled data) \\
\hline Treatment & $\begin{array}{c}\text { Okra equivalent } \\
\text { yield }\left(\mathrm{t} \mathrm{ha}^{-1}\right)\end{array}$ & $\begin{array}{c}\text { Production } \\
\text { efficiency } \\
\left(\mathrm{kg}^{-1} \mathrm{ha}^{-1} \mathrm{day}^{-1}\right)\end{array}$ & $\begin{array}{c}\text { Ascorbic } \\
\text { acid } \\
\left(\mathrm{mg} \mathrm{l00} \mathrm{g}^{-1}\right)\end{array}$ & $\begin{array}{c}\text { Land } \\
\text { equivalent } \\
\text { ratio }\end{array}$ & $\begin{array}{c}\text { Aggresivity } \\
\text { Relative } \\
\text { crowding } \\
\text { coefficient }\end{array}$ & $\begin{array}{c}\text { Benefit :Cost } \\
\text { ratio }\end{array}$ \\
\hline Sole okra & 11.54 & 144.19 & 24.27 & 1.00 & MC & IC & - & 2.06 \\
Sole cowpea & - & - & - & 1.00 & - & - & - & 1.26 \\
Sole amaranthus & - & - & - & 1.00 & - & - & - & 1.44 \\
Sole radish & - & - & - & 1.00 & - & - & - & 0.80 \\
Sole palak & - & - & - & 1.00 & - & - & - & 1.07 \\
Okra+cowpea & 15.67 & 195.88 & 25.28 & 1.56 & -0.05 & 0.05 & 13.75 & 2.61 \\
Okra+amaranthus & 10.13 & 126.57 & 20.73 & 1.15 & 0.05 & -0.05 & 1.90 & 1.48 \\
Okra+radish & 9.02 & 112.69 & 19.99 & 1.12 & -0.02 & 0.02 & 1.77 & 1.33 \\
Okra+palak & 11.53 & 144.13 & 21.83 & 1.41 & -0.04 & 0.04 & 3.75 & 1.78 \\
SEm \pm & 0.63 & 12.88 & 0.88 & - & - & - & - & - \\
CD $(p=0.05)$ & 1.81 & 37.31 & 2.40 & - & - & - & - & - \\
\hline
\end{tabular}

and 2.61 respectively). This result was in conformity with the findings of (Matusso et al., 2014) who found that among different intercropping combinations maize+soybean intercropping model were most remunerative with highest net return and maximum $\mathrm{B}: \mathrm{C}$ ratio values.

\section{Conclusion}

Intercropping in okra was found promising than its sole cropping. Among different treatments growing of cowpea with okra in 1:1 proportion was found best for maximum okra equivalent yield, greater monetary benefit, highest production efficiency and higher ascorbic acid content of the fruits as this system of intercropping was efficient user of biological resources. Intercropping radish with okra was least remunerative and recorded minimum values for most of the vegetative, reproductive and quality parameters.

\section{References}

Addo-Quaye, A.A., Darkwa, A.A., Ocloo, G.K., 2011. Yield and productivity of component crops in a maize-soybean intercropping system as affected by time of planting and spatial arrangement. ARPN Journal of Agricultural and 
Biological Science 6, 50-57.

Dahanayake, N., Inoka, K.P.I., Dissanayaka, D.M.P., Madhushani, P.A., 2015.Vegetative and reproductive growth of some selected vegetables with legumes under mono-cropping vs mix-cropping and determine the soil microbial activity. International Journal of Scientific and Research Publications 5, 1-9.

Fustec, J., Lesuffleur, F., Mahieu, S., Cliquet, J.B., 2010. Nitrogen rhizodeposition of legumes-a review. Agronomy for Sustainable Development 30, 57-66.

Hadidi, N., Sharaiha, R., Debei, A.L.H., 2011. Effect of intercropping on the performance of some summer vegetable crops grown under different row arrangements. Lucrari stiintifice 54, 11-17.

Hugar, H.Y., Palled, Y.B., 2008. Effect of intercropped vegetables on maize and associated weeds in maizevegetable intercropping systems. Karnataka Journal of Agricultural Science 21, 159-161.

John, S.A., Mini, C., 2005. Biological efficiency of intercropping in okra [Abelmoschus esculentus (L.) Moench]. Journal of Tropical Agriculture 43, 33-36.

Kandeyang, S., 2004. Nutrient management in okra based intercropping system. PhD Thesis submitted to Birsa Agricultural University, Ranchi, 30-50.

Lyocks, S.W.J., Tanimu, J., Dauji, L.Z., 2013. Growth and yield parameters of ginger as influenced by varying populations of maize intercrop. Journal of Agricultural Crop Research 1, 24-29.

Matusso, J.M.M., Mugwe, J.N., Mucheru-Muna, M., 2014. Effect Of different maize (Zea mays L.)-Soybean (Glycine $\max (\mathrm{L}$.$) Merrill) Intercropping patterns$ on yields and its economics. Academia Journal of Agricultural Research 2, 159-166.

Mohamed, F.M., Mousa, M.A.M., 2007. Yield of Crops in Within-Kow Intercropped Okra-Cowpea or OkraCucumber. International Journal of Vegetable Science 13, 33-48.

National Horticulture Board, 2013. National Horticulture Board Data base Available from http://nhb.gov.in/.

Nilanthi, D., Inoka, K.P.I., Dissanayaka, D.M.P., Madhushani, P.A., 2015. Vegetative and reproductive growth of some selected vegetables with legumes under mono-cropping vs mixcropping and determine the soil microbial activity. International Journal of Scientific and Research Publications 5, 1-9.

Nursima, K.A., 2009. Profitability of intercropping corn with mungbean and peanut, USM. R\&D Journal 17, 65-70.

Odeleye, F.O., Odeleye, O.M.O., Dada, A.O., Olaleye, O.A., 2005. The response of okra to varying levels of poultry manure and plant population density under sole cropping. Journal of Food Agriculture and Environment 3, 68-74.

Panse, V.G., Sukhatme, P.V., 2000. Statistical methods for agricultural workers. ICAR Publications, New Delhi-12, 381 .

Ranganna, S., 1986. Analysis and quality control for fruit and vegetable products. $2^{\text {nd }}$ edition. Tata. Mc Graw-Hill publishing company ltd. New Delhi, 25.

Sharma, R.P., Rahaman, K.R., Singh, A.K., 2009. Fodder productivity and economics of pearlmillet with legumes intercropping under various row proportions. Indian Journal of Agronomy 54, 301-305.

Seran, T.H., Brintha, I., 2009. Study on determining a suitable pattern of capsicum (Capsicum annum L.)-vegetable cowpea (Vigna unguiculata L.) intercropping. Karnataka Journal of Agricultural Sciences 22, 1153-1154.

Singh, R.V., 1993. Production potential and economics of vegetables intercropped with rainfed okra. Indian Journal of Horticulture 50, 73-76. 